\title{
Effects of Aluminium Chloride Exposure on the Histology of the Cerebral Cortex of Adult Wistar Rats
}

Adebayo Adekunle Buraimoh (Corresponding Author)

Assistant Lecturer, Department of Human Anatomy, Faculty of Medicine

Ahmadu Bello University, Zaria, Nigeria

Tel: 234-802-819-3042Ｅ-mail: adebayo.buraimoh@gmail.com

Samuel Adeniyi Ojo
Professor, Department of Veterinary Anatomy, Faculty of Veterinary Medicine

Ahmadu Bello University, Zaria, Nigeria

Tel: 234-803-703-7316_E-mail: ojo_sam@yahoo.com

Joseph Olajide Hambolu

Professor, Department of Veterinary Anatomy, Faculty of Veterinary Medicine

Ahmadu Bello University, Zaria, Nigeria

Tel: 234-803-450-9759Ｅ-mail: hambolujoseph@yahoo.com

\begin{abstract}
Sunday Samuel Adebisi
Associate Professor, Department of Human Anatomy, Faculty of Medicine

Ahmadu Bello University, Zaria, Nigeria

Tel: 234-802-596-8844Ｅ-mail: sam_adebisi@yahoo.com
\end{abstract}

Received: February 20, 2012 Accepted: March 5, 2012

doi: 10.5296/jbls.v3i1.1421 URL: http://dx.doi.org/10.5296/jbls.v3i1.1421 


\section{Abstracts}

Aluminium ( $\mathrm{Al}$ ) is presents in many manufactured foods, medicines and is also added to drinking water for purification purposes. Human exposure to Al has been increasing over the last decades. Al exposure and neurological impairments demonstrate mixed findings. The cerebral cortex is a sheet of neural tissue that is outer-most to the cerebrum of the mammalian brain and it plays a key role in memory, attention, perceptual awareness, thought, language, and consciousness. The objectives of this study was to investigate the possible effects that aluminium Chloride could have on the histology of cerebral cortex. Total of twenty adult wistar rats were used for this experiment. The wistar rats were divided into five groups; group I was the control, group II received $475 \mathrm{mg} / \mathrm{Kg}$, group III received $950 \mathrm{mg} / \mathrm{kg}$, group IV received $1,425 \mathrm{mg} / \mathrm{kg}$ and group $\mathrm{V}$ received $1,900 \mathrm{mg} / \mathrm{kg}$ via oral intubation for a duration of Eight weeks. The wistar rats were humanly sacrificed and the brain was removed and immediately fixed in bouin fluid. The histological observations of the aluminium treated groups revealed extensive neuronal vacuolation and necrosis (neuro-degeneration) of the cerebral cortex of wistar rats.Based on our observations, we therefore conclude that Aluminium chloride exposure has neurodegenerative effects on the histology of cerebral cortex of adult wistar rats especially at higher dose. Therefore, caution should be taken in its usage.

Keywords: Effects, Aluminium chloride, Exposure, Histology, Cerebral cortex, Wistar rats

\section{Introduction:}

Nervous system is a vulnerable target for toxicants due to critical voltages which must be maintained in the cells and the all responses when voltages reach threshold levels. Aluminium (Al) has the potential to be neurotoxic in human and animals. It presents in many manufactured foods and medicines and is also added to drinking water for purification purposes (Newairy et al., 2009). Al is widely used in antacid drugs, as well as, in food additives and tooth paste (Abbasali et al., 2005). Environmental pollution with different aluminium containing compounds, especially those in industrial waste expose people to higher than normal levels of Al (Kloppel et al., 1997). Particulate matters distributed by cement - producing factories contain, high amount of $\mathrm{Al}$, and animals and populations residing in the vicinity are exposed to the pollution (Shehla et al., 2001). Although, aluminum has been implicated in Alzheimer's disease, Parkinsonism, Dementia complex and causes extensive damage to the nervous system, to date the mechanism of Al neurotoxicity has not been fully elucidated (Niu et al., 2007). Patients on dialysis or on long-term treatment with total parenteral nutrition have been shown to accumulate this metal in different organs. (Alfrey et al., 1976; Yokel and McNamara, 2001; Klein, 1993). Al is a possible contributing factor in Alzheimer's disease (Campbell, 2002). Evidence for the contribution of Al to Alzheimer's disease (AD) remains contradictory (Flaten, 2001; Gupta et al., 2005). However, epidemiological studies have indicated a link between $\mathrm{Al}$ in drinking water and $\mathrm{AD}$ and a variety of human and animal studies have implicated learning and memory deficits after Al exposure. (Buraimoh et al., 2011a; Exley, 2005; Yokel, 2000).It was also postulated by Buraimoh et al., 2011b: that Aluminium chloride exposure has negative effects on behaviour of adult wistar rats (i.e. alter behaviour). It has been shown clearly that aluminium 
accumulates in various mammalian tissues such as brain, bone, liver and kidney (Wills et al., 1993; Sahin et al., 1994) and is accompanied by renal failure (Alfrey, 1980) or associated with age (Gómez et al., 1997).

The cerebral cortex is a sheet of neural tissue that is outer-most to the cerebral of the mammalian brain. It plays a key role in memory, attention, perceptual awareness, thought, language, and consciousness. It also integrates higher mental functions, general movement, visceral functions, and behavioral reactions. (Brodal, 1977;Cauller, 1995). It is constituted of up to six horizontal layers, each of which has a different composition in terms of neurons and connectivity. Neurons of the cerebral cortex are grouped into six main layers which include the following:

1. The molecular layer I

2. The external granular layer II

3. The external pyramidal layer III

4. The internal granular layer IV:

5. The internal pyramidal layer $\mathrm{V}$

6. The multiform layer VI, (Jones,1998; Gilbert and Sigman, 2007; Shipp and Stewart., 2007 )

\subsection{Aims and Objectives}

This study was designed in order to describe any possible effects (histological changes) that Aluminium Chloride exposure could have on the cerebral cortex of adult wistar rats.

\section{Materials and Methods}

This experiment was conducted in the Department of Human Anatomy, Faculty of Medicine, Ahmadu Bello University, Zaria, Kaduna State, Nigeria.

\subsection{Experimental Animals}

Twenty (20) Adult wistar rats were used for this experiment. The wistar rats were housed in a stainless steel cages maintained at standard environmental conditions (12h-12h light-dark cycle with light on at AM) with sufficient food, water and under good ventilation. The wistar rats were kept for two weeks (14days) before commencement of administration. This was to enable the wistar rats to acclimatise.

\subsection{Experimental Design}

The wistar rats were divided into five groups: control group I was given distil water while the four Aluminium exposed groups were given various concentrations of aluminium chloride as follows:

Group II received $475 \mathrm{mg} / \mathrm{Kg}$

Group III received $950 \mathrm{mg} / \mathrm{kg}$ 


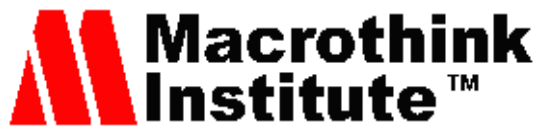

Group IV received $1,425 \mathrm{mg} / \mathrm{kg}$

Group V received 1,900mg/kg (LD25)

The LD50 was $3,800 \mathrm{mg} / \mathrm{kg}$. The duration of administration was Eight weeks.

\subsection{Experimental Procedure}

After oral administration of various concentrations of Aluminium chloride to each group of the Wistar rats except group I (the control) for a duration of eight weeks, the wistar rats were humanly sacrificed and brain tissues were immediately removed and fixed in Bouin's fluid. Tissue preparation method for histological analysis was differentiated into the following stages; fixation, tissue processing, sectioning, staining and photomicrography. The tissue preparation was carried out using standard techniques in accordance with Gurr, (1962); Culling (1963); and Bradbury (1992). Haematoxylin and Eosin (H\&E) staining was used to demonstrate general cell structure while Hirano-Zimman method was used for nerve cells and fibres (Hirano and Zimmerman, 1962; Luna, 1968).

\section{Results}

3a. Microscopic Examination of Tissues (H\&E stain)

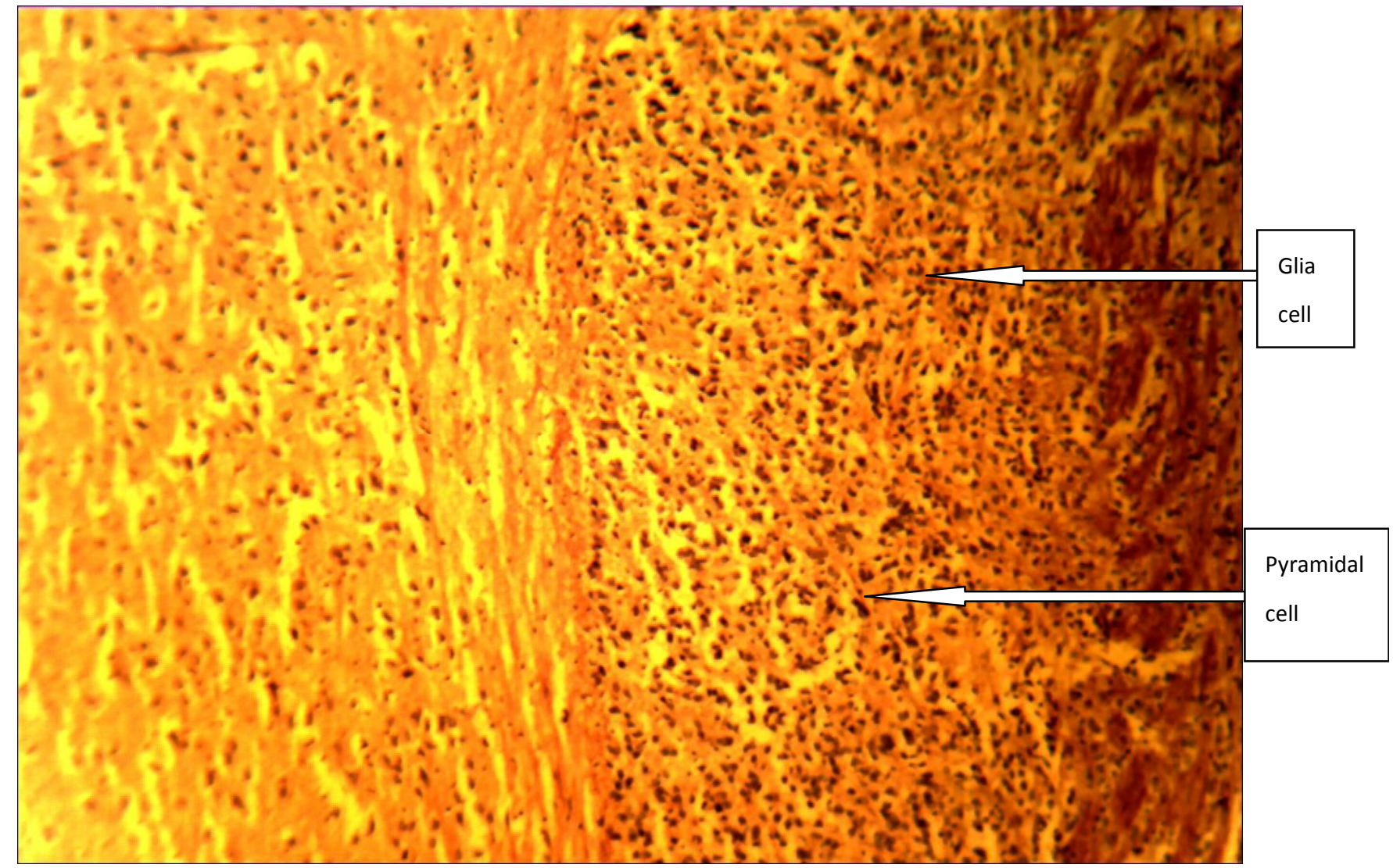

Plate 1: L.S. of Normal Cerebral Cortex of wistar rats of control group stained with H\&E. $\mathrm{X} 100$ 


\section{Macrothink}

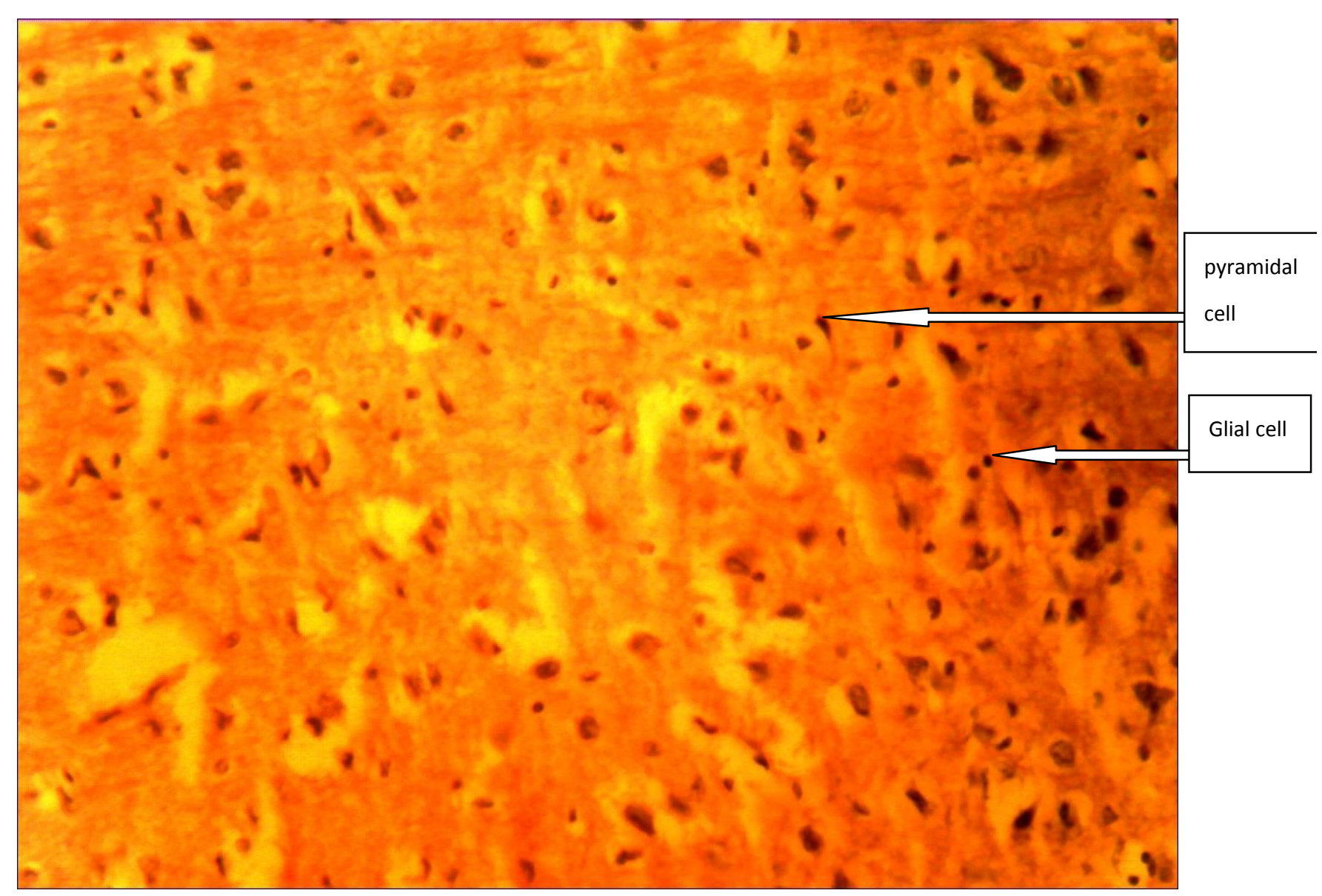

Plate 2: L.S. of Normal Cerebral Cortex of wistar rats of control group stained with H\&E. Mag.X250 


\section{Ml Macrothink}

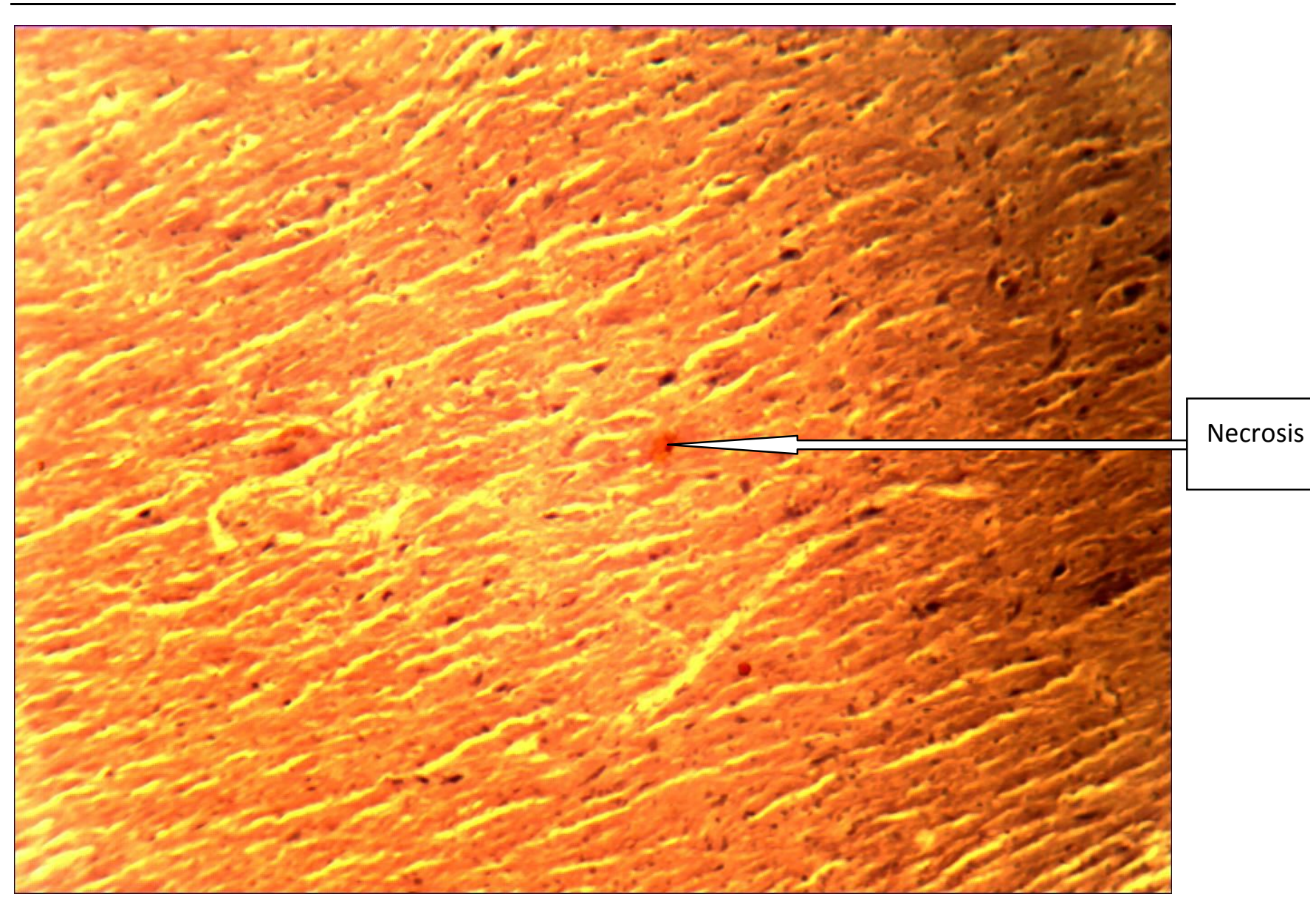

2012, Vol. 3, No. 1

Plate 3. L.S. showing necrosis of the Cerebral Cortex of wistar rats of group II stained with H\&E. X100 


\section{Ml Macrothink}

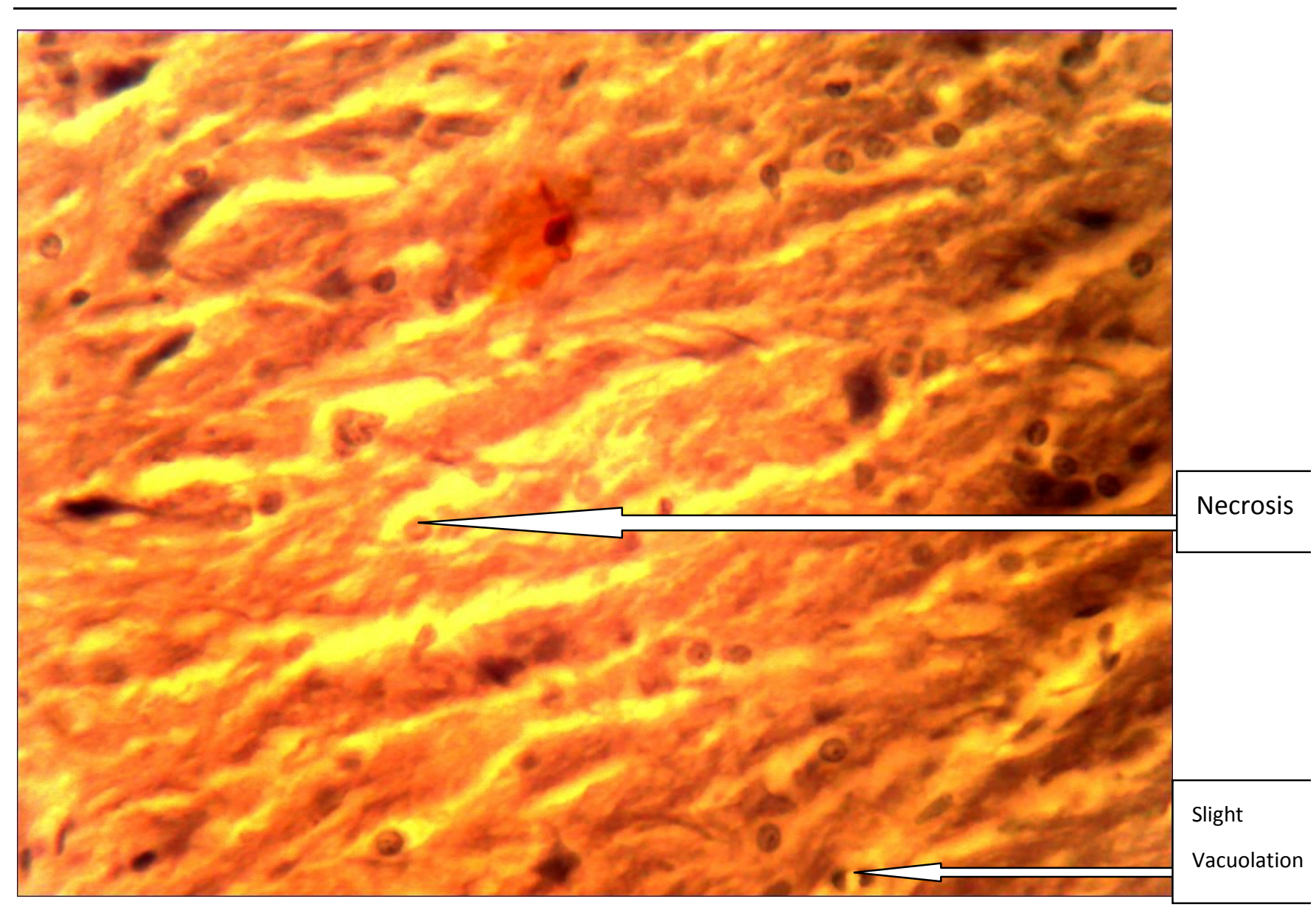

Plate 4. L.S. showing slight neuronal vacuolation and necrosis of the Cerebral Cortex of wistar rats of group II stained with H\&E.X250 


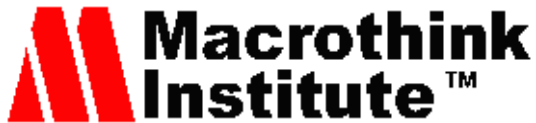

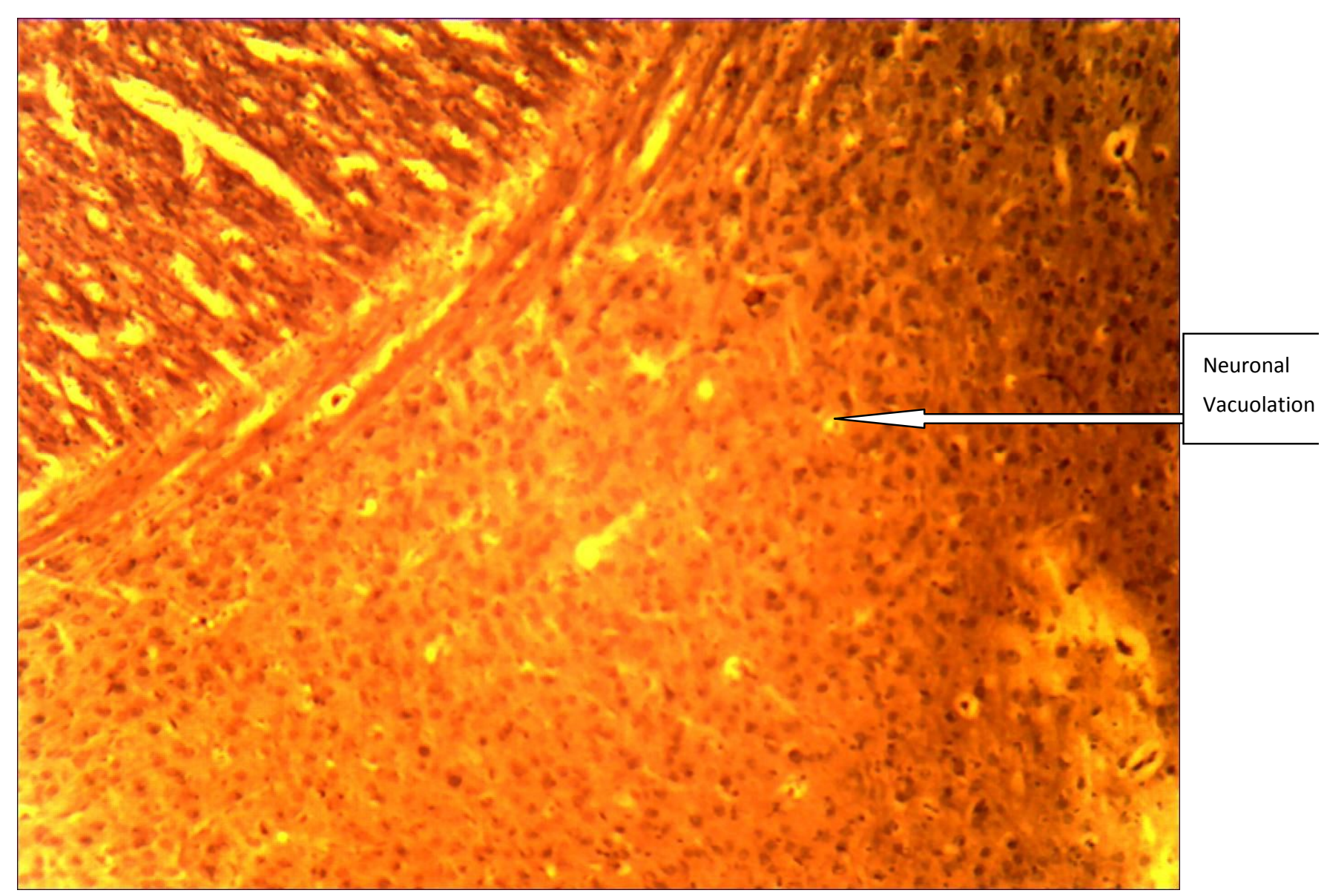

Plate 5. L.S. Showing slight neuronal vacuolation and Necrosis of the Cerebral Cortex of wistar rats of group III, stained with H\&E. X100 


\section{Ml Macrothink}

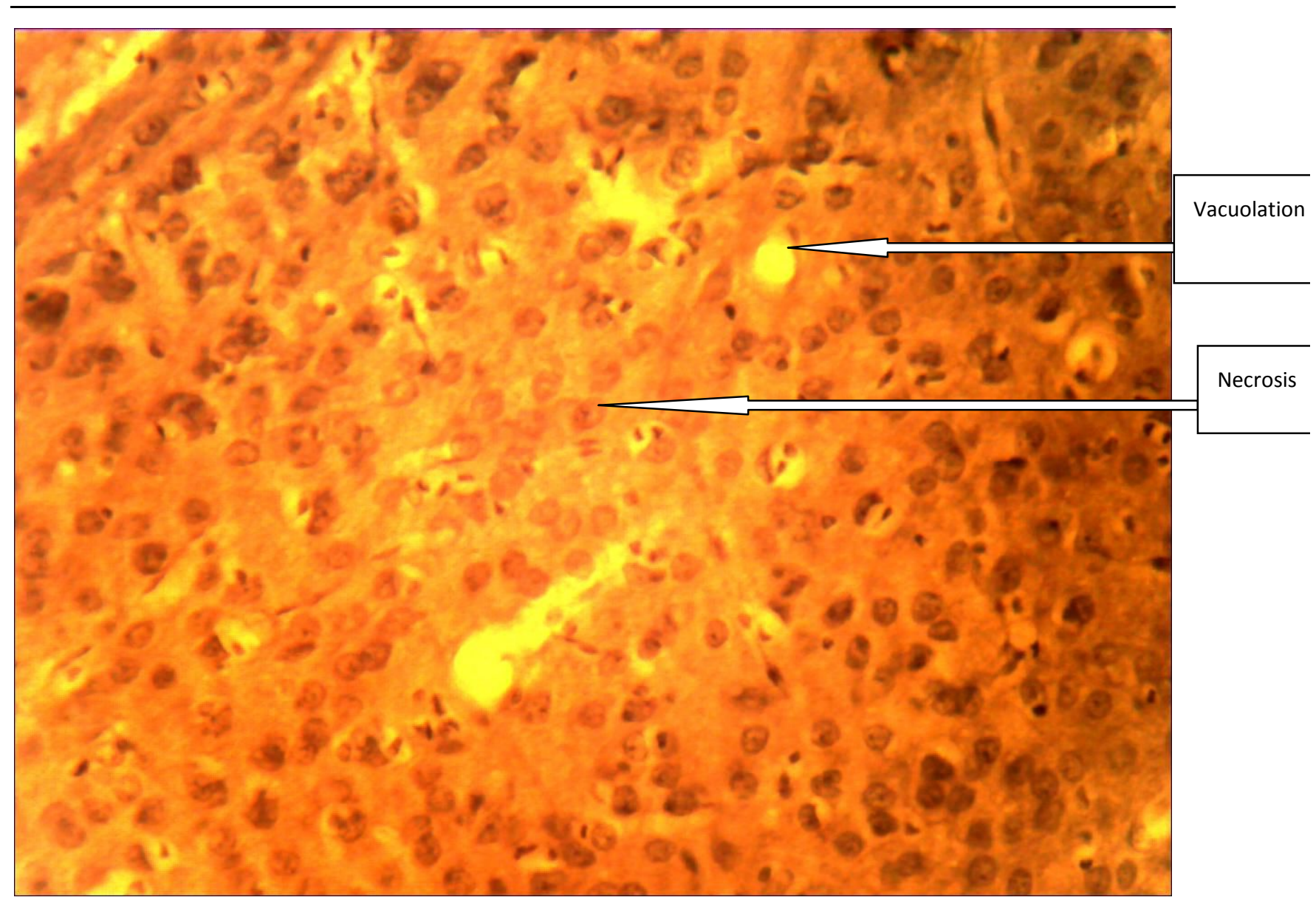

Plate 6. L.S. Showing slight neuronal vacuolation and Necrosis of the Cerebral Cortex of wistar rats of group III, stained with H\&E.X250 


\section{I Macrothink}

Journal of Biology and Life Science

ISSN 2157-6067 2012, Vol. 3, No. 1

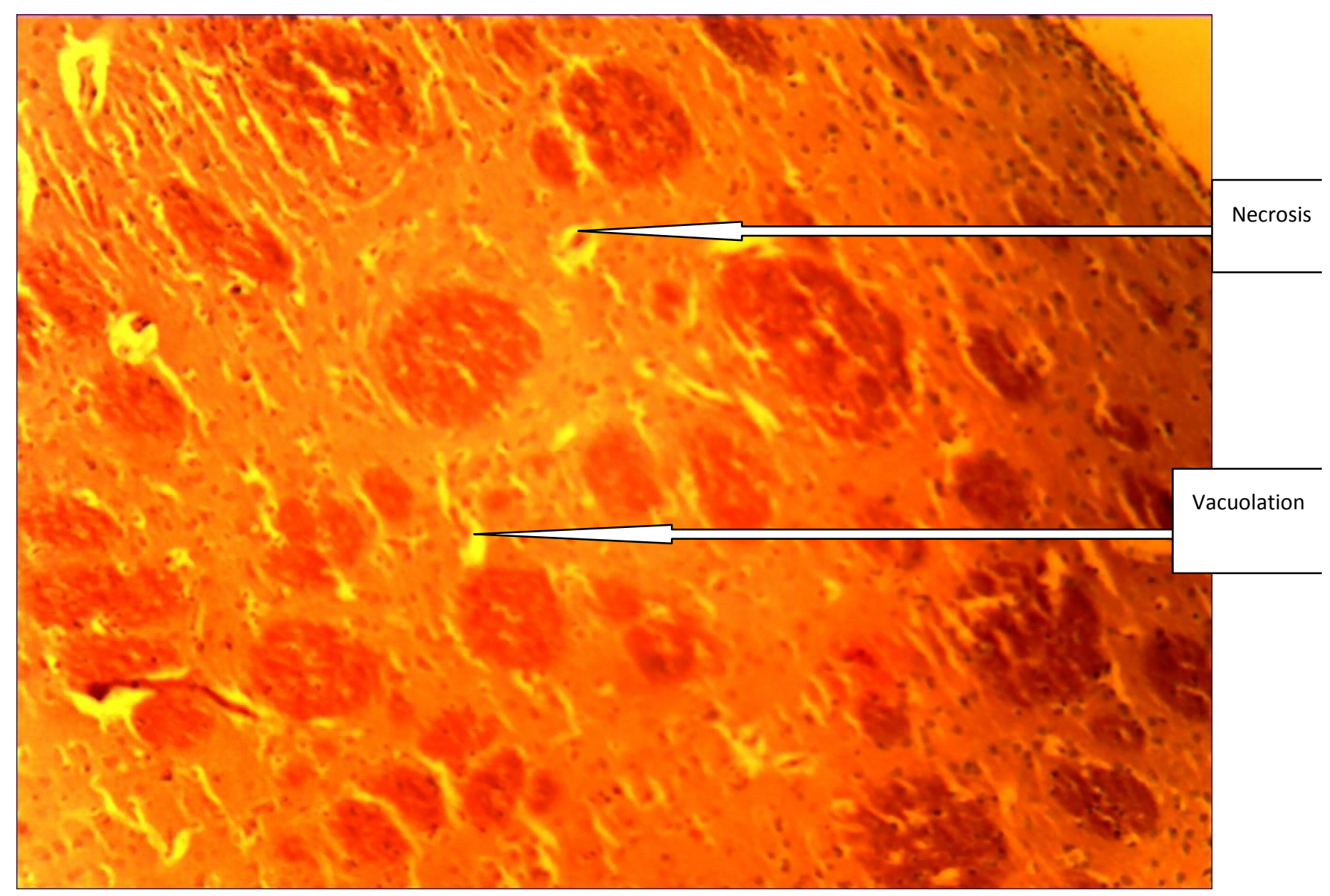

Plate 7. L.S. Showing neuronal vacuolation and Necrosis of the Cerebral Cortex of wistar rats of group IV, stained with H\&E X100 


\section{I Macrothink}

Journal of Biology and Life Science

ISSN 2157-6067

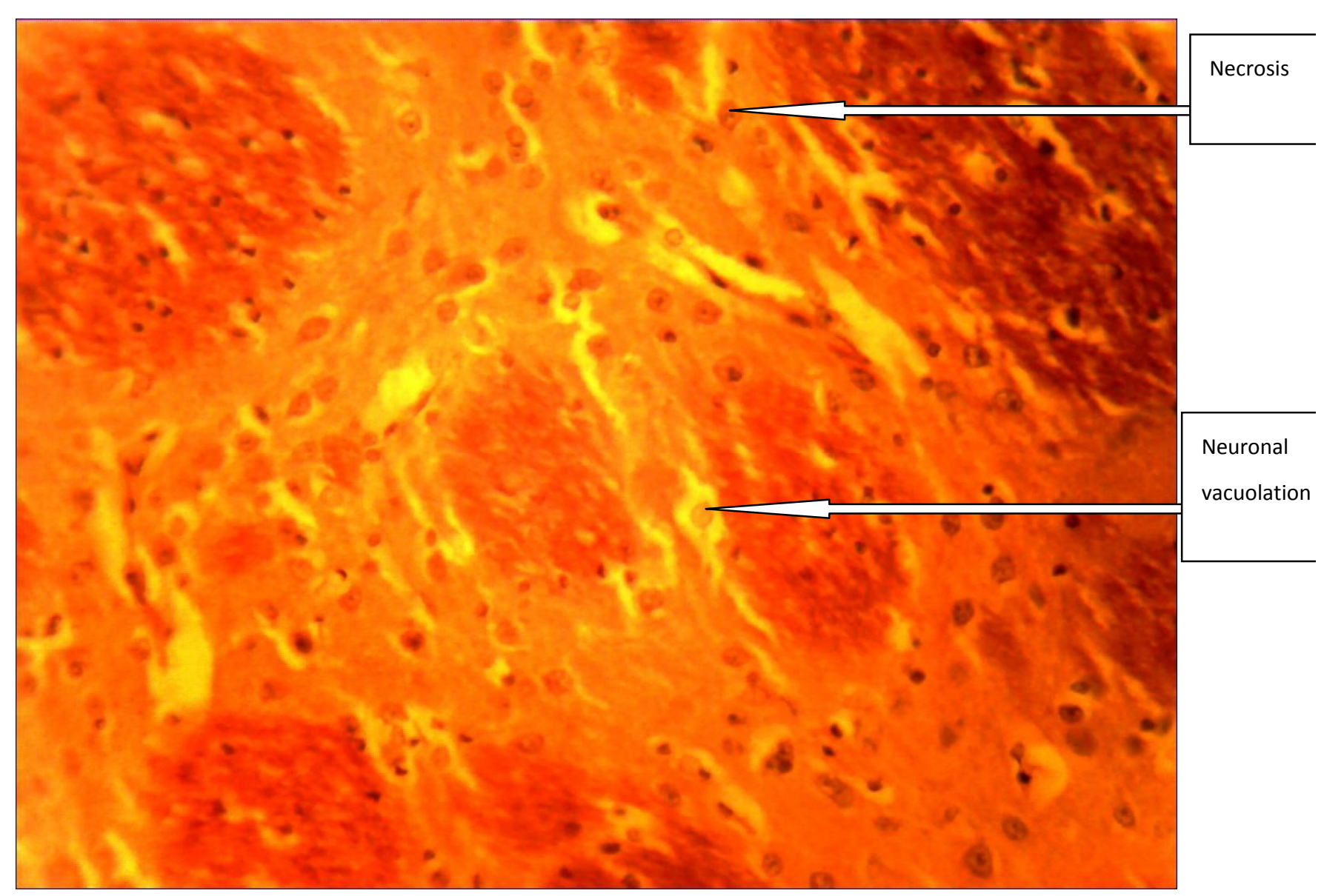

Plate 8. L.S. Showing slight neuronal vacuolation and Necrosis of the Cerebral Cortex of wistar rats of group IV, stained with H\&E.X250 


\section{MInstitute ${ }^{\text {Mnk }}$}

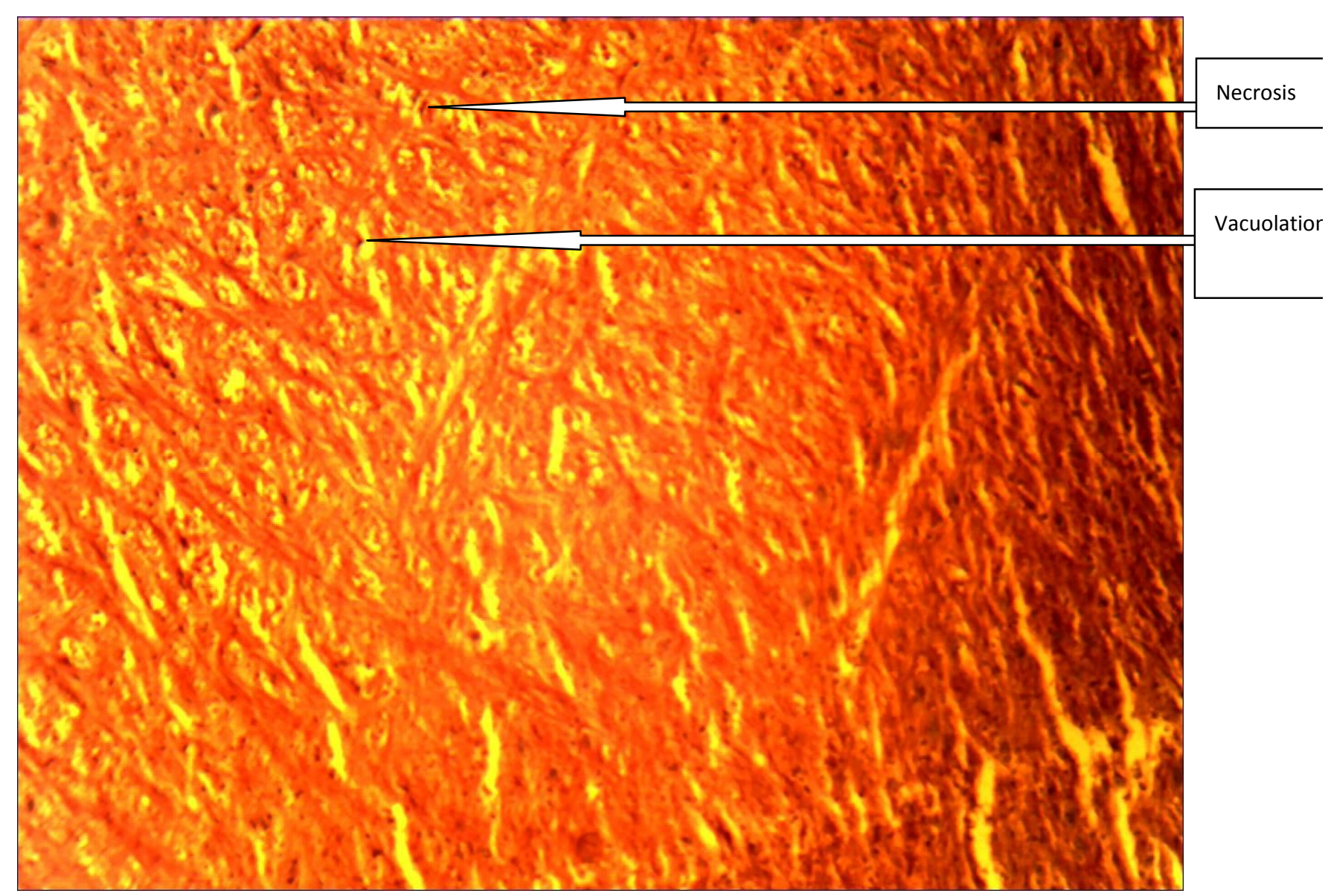

Plate 9. L.S Showing extensive neuronal Vacuolation and necrosis of the Cerebral Cortex of wistar rats of group V, stained with H\&E. X100 


\section{Macrothink}

Journal of Biology and Life Science

ISSN 2157-6067

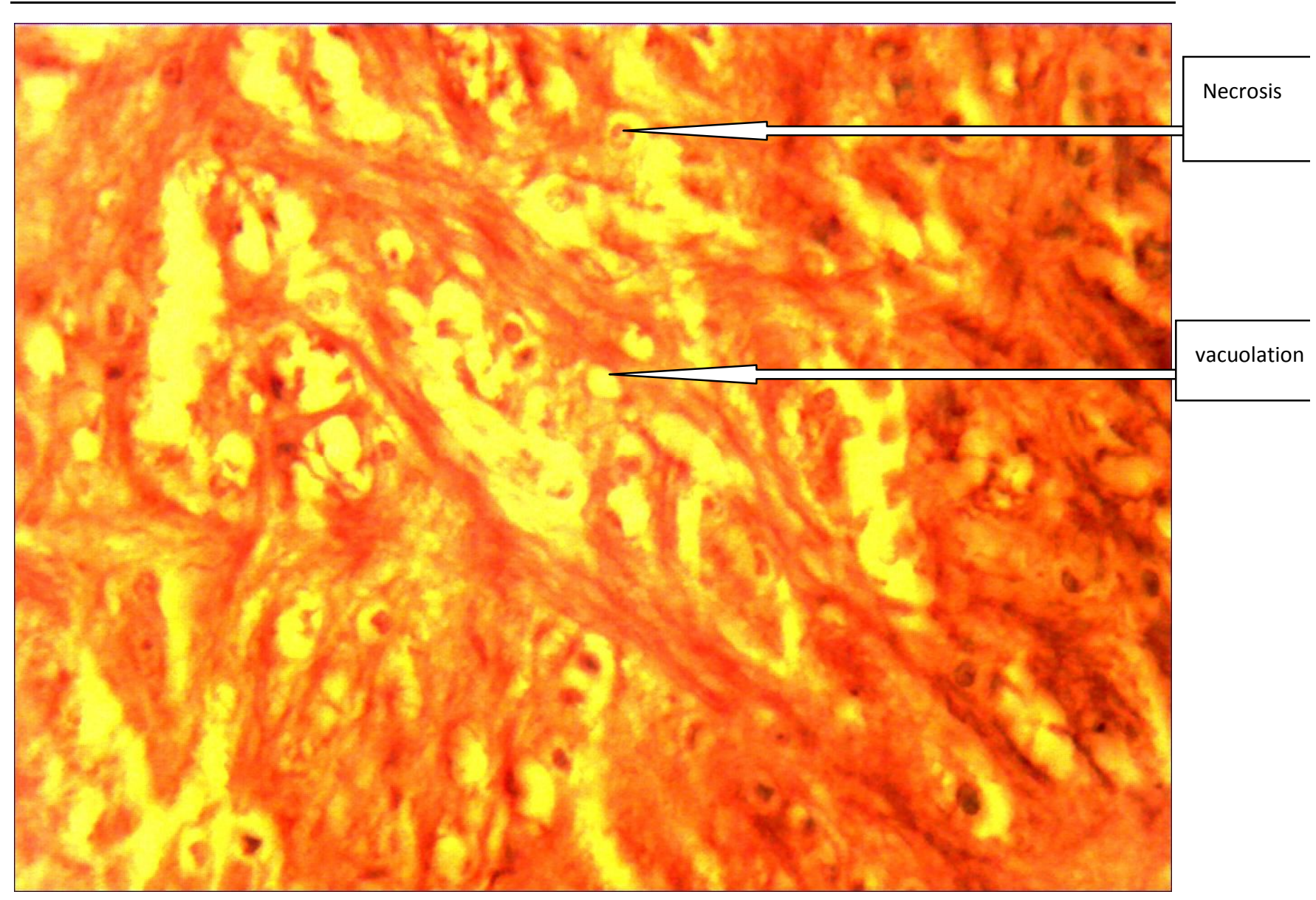

Plate 10. Showing extensive neuronal vaculation and necrosis of the Cerebral Cortex of wistar rats of group V, stained with H\&E .X250 


\section{MIMacrothink}

3b. Microscopic Examination of Tissues (Hirano-Zimmerman method)

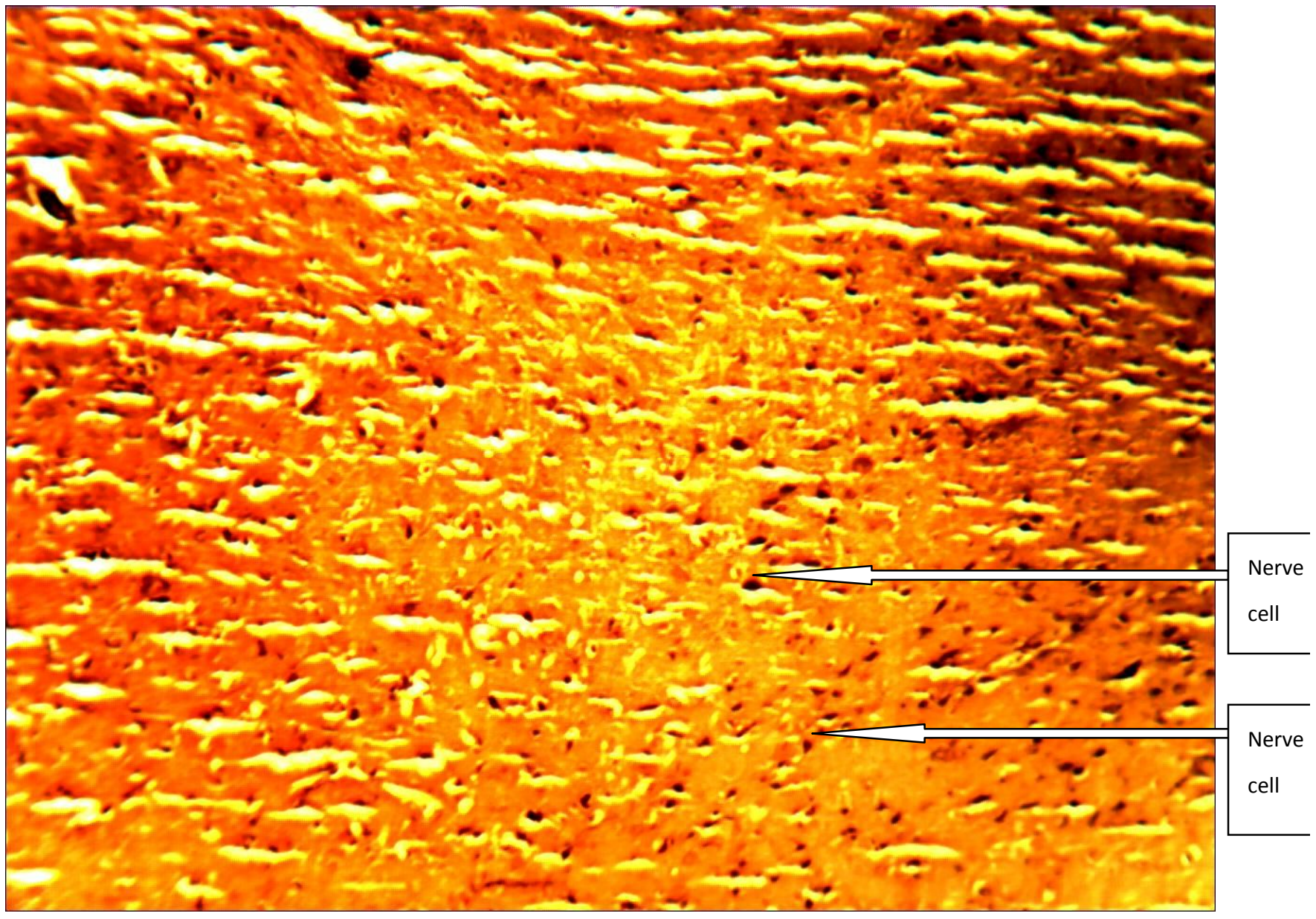

Plate 11. L.S. of normal Cerebral cortex of wistar rats of group I .X100 


\section{MIMacrothink}

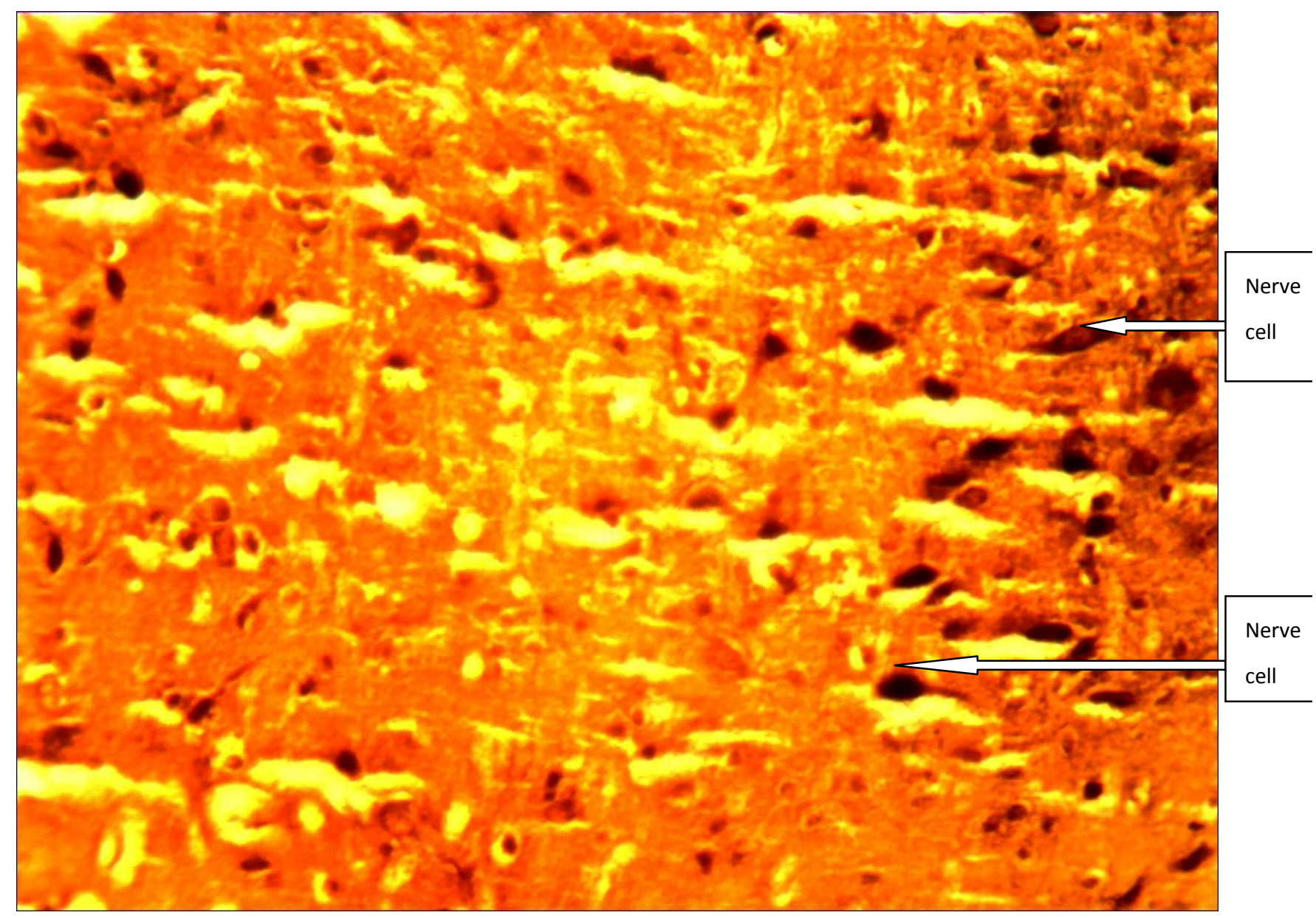

Plate 12. L.S. of normal Histology of the Cerebral Cortex of wistar rats of group I .X250 


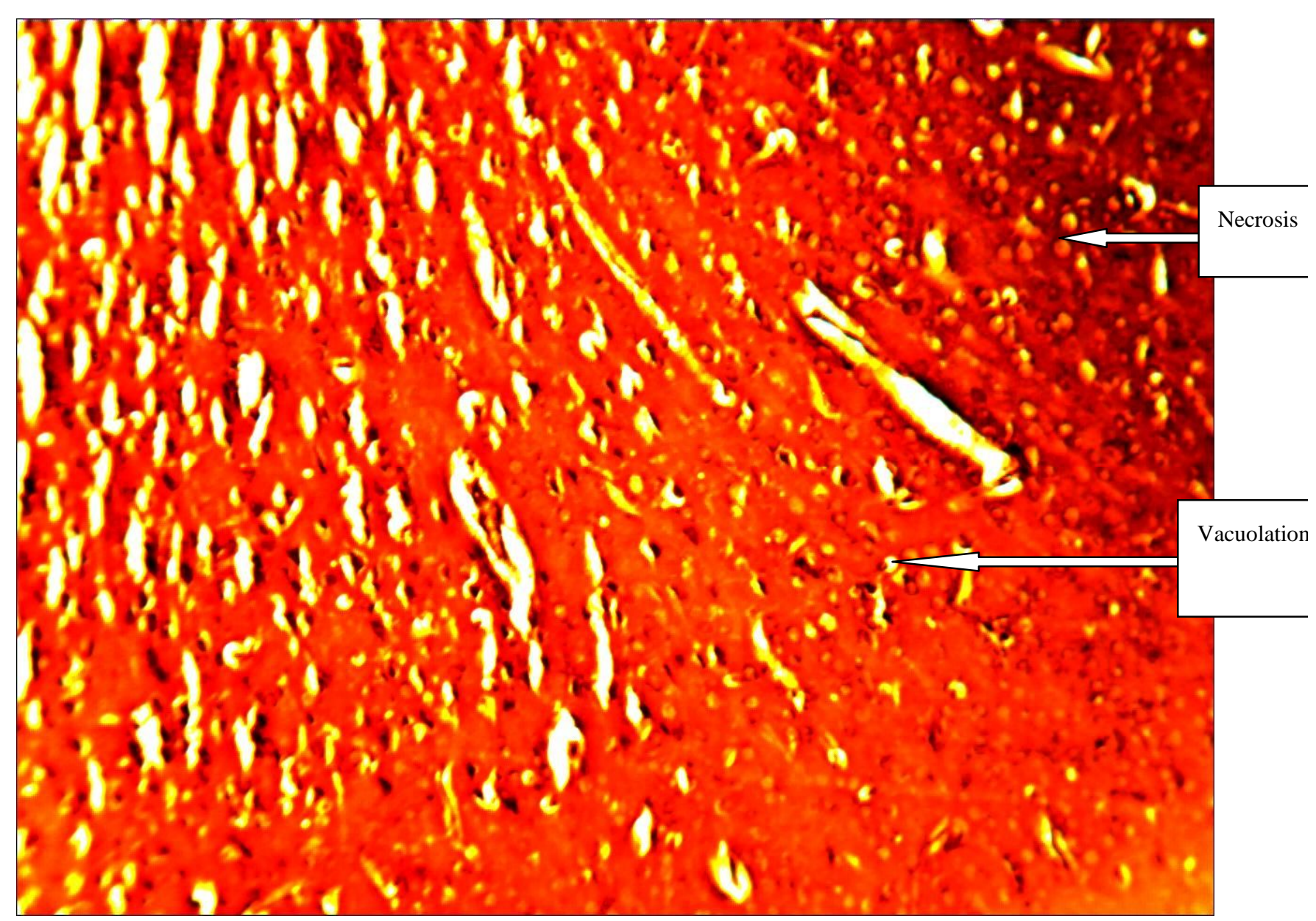

Plate 13. L.S. of neuronal vacuolation and necrosis of the Cerebral cortex of wistar rats of group II. $\mathrm{X} 100$ 


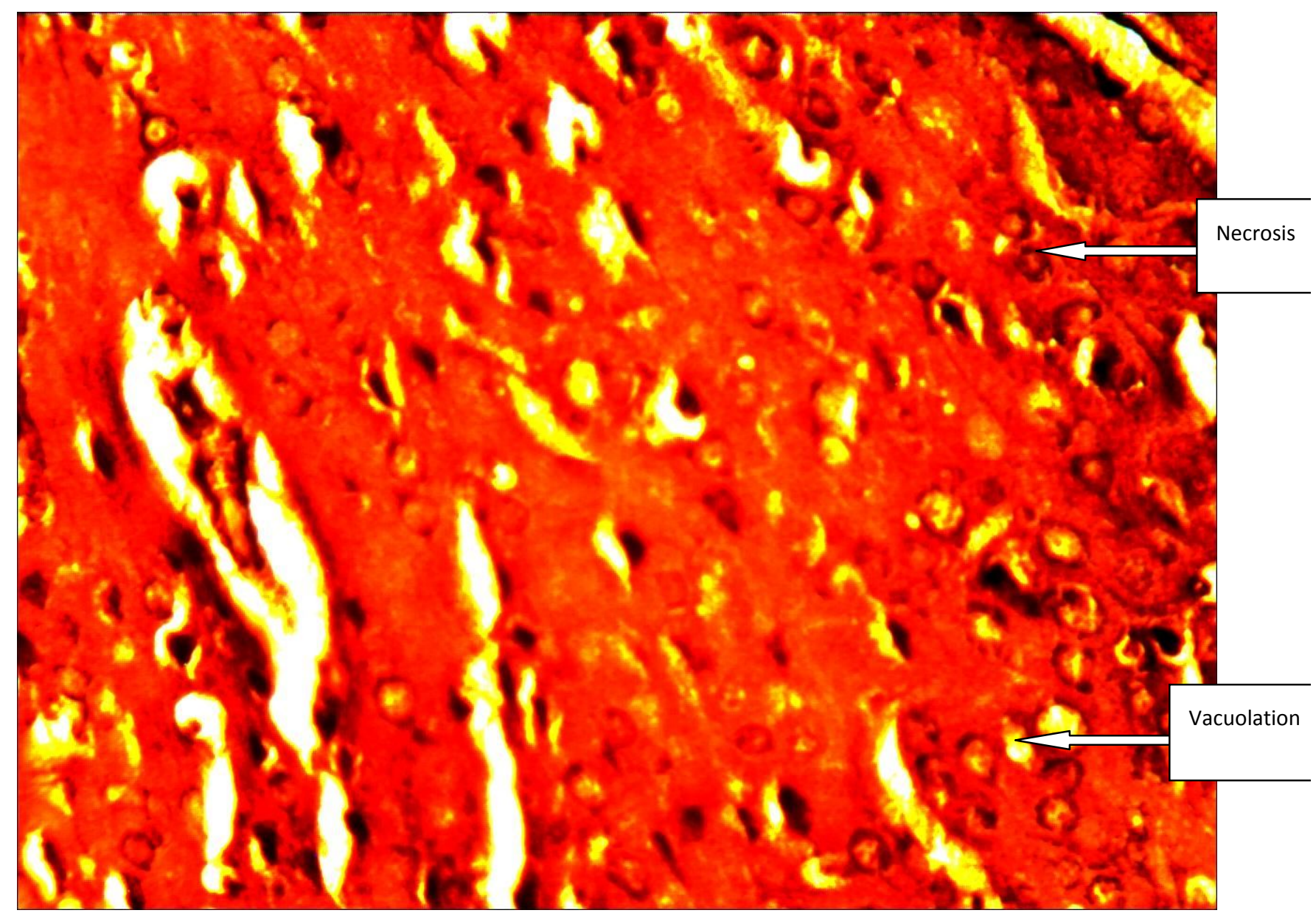

Plate 14. L.S. of neuronal vacuolation and necrosis of the cerbral Cortex of wistar rats of group II .X250 


\section{MInstitute ${ }^{\text {Mink }}$}

Journal of Biology and Life Science

ISSN 2157-6067

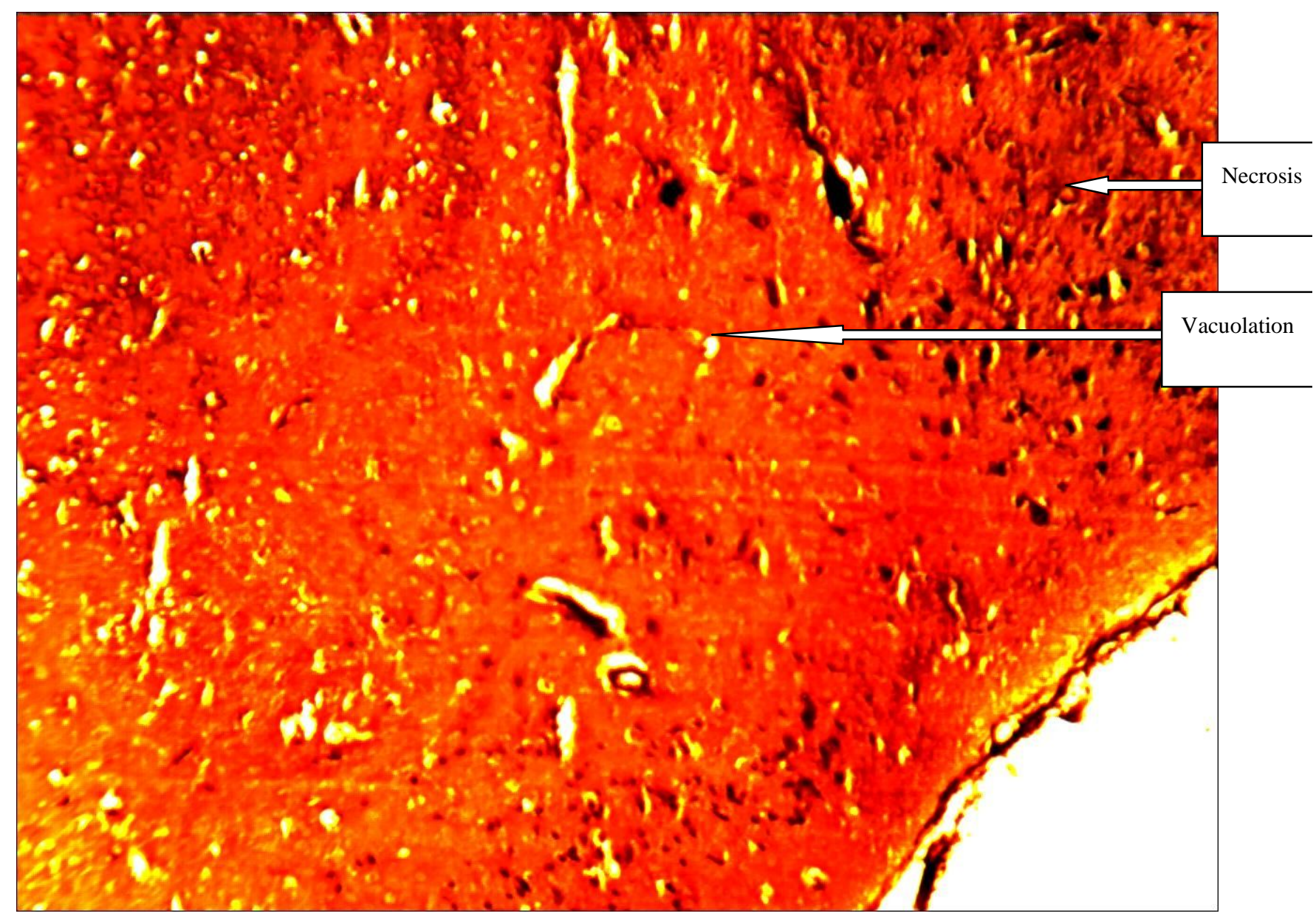

Plate 15.L.S.of neuronal vacuolation and necrosis of the cerbral Cortex of wistar rats of group III .X100 


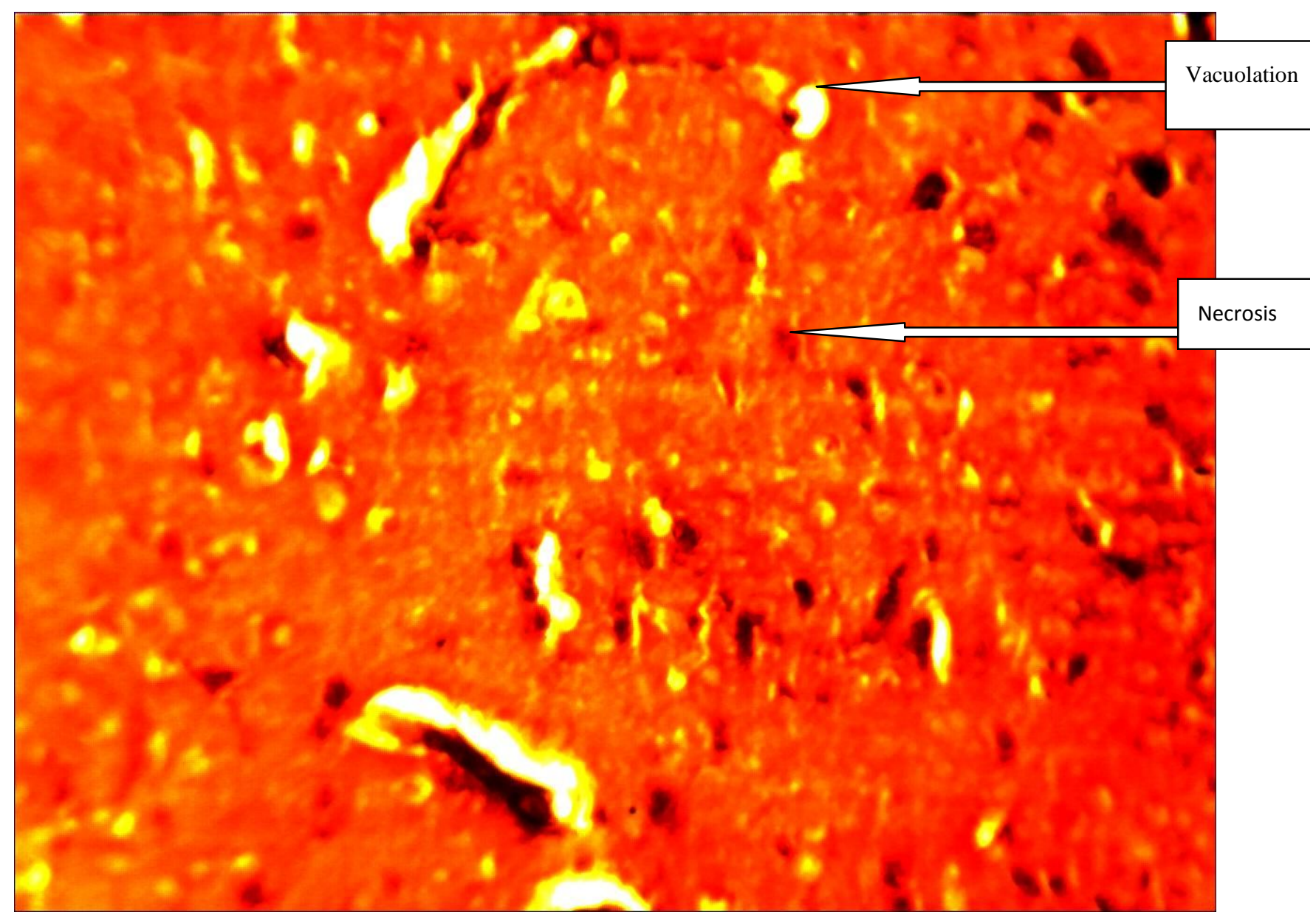

Plate 16. L.S. of neuronal vacuolation and necrosis of the cerbral Cortex of wistar rats of group III .X250 


\section{MInstitute ${ }_{\text {Mnk }}^{\text {Macrothink }}$}

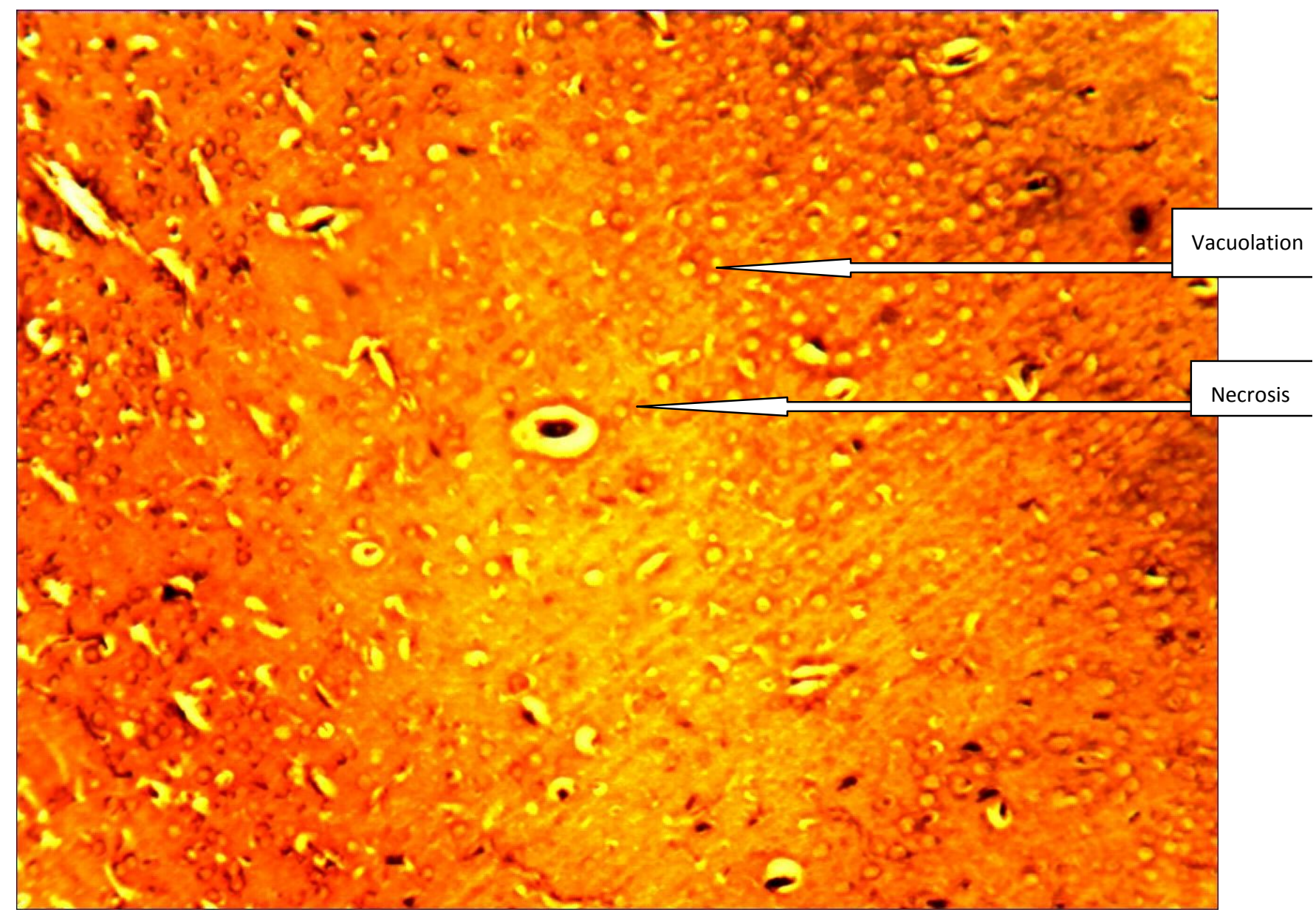

Plate 17.L.S. of neuronal vacuolation and necrosis of the cerbral Cortex of wistar rats of group IV .X100 


$\begin{array}{ll}\text { Alinstitute } & \text { 2012, Vol. 3, No. } 1\end{array}$

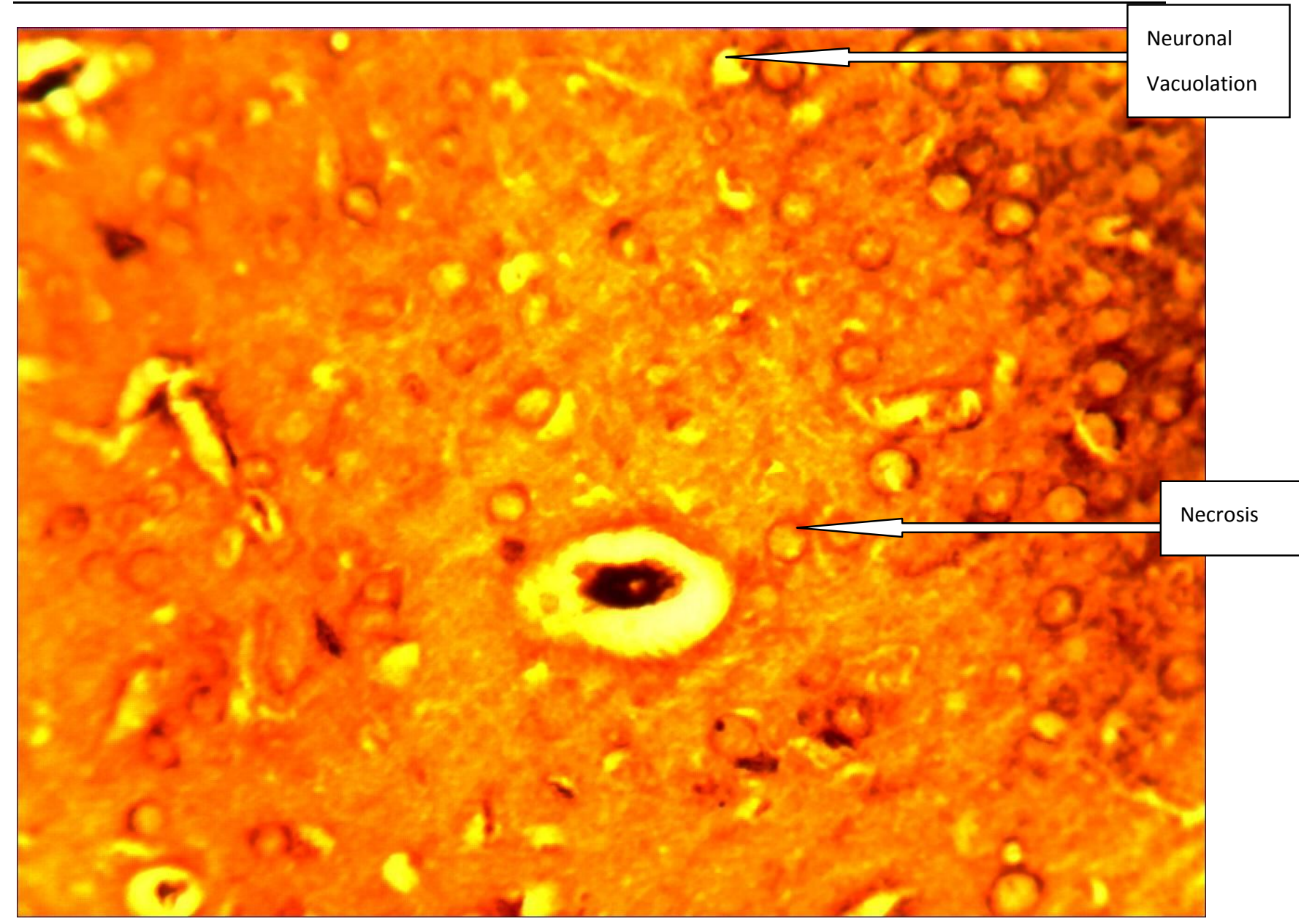

Plate 18. L.S. of neuronal vacuolation and necrosis of the cerbral Cortex of wistar rats of group IV .X250 


\section{$\Lambda$ Macrothink}

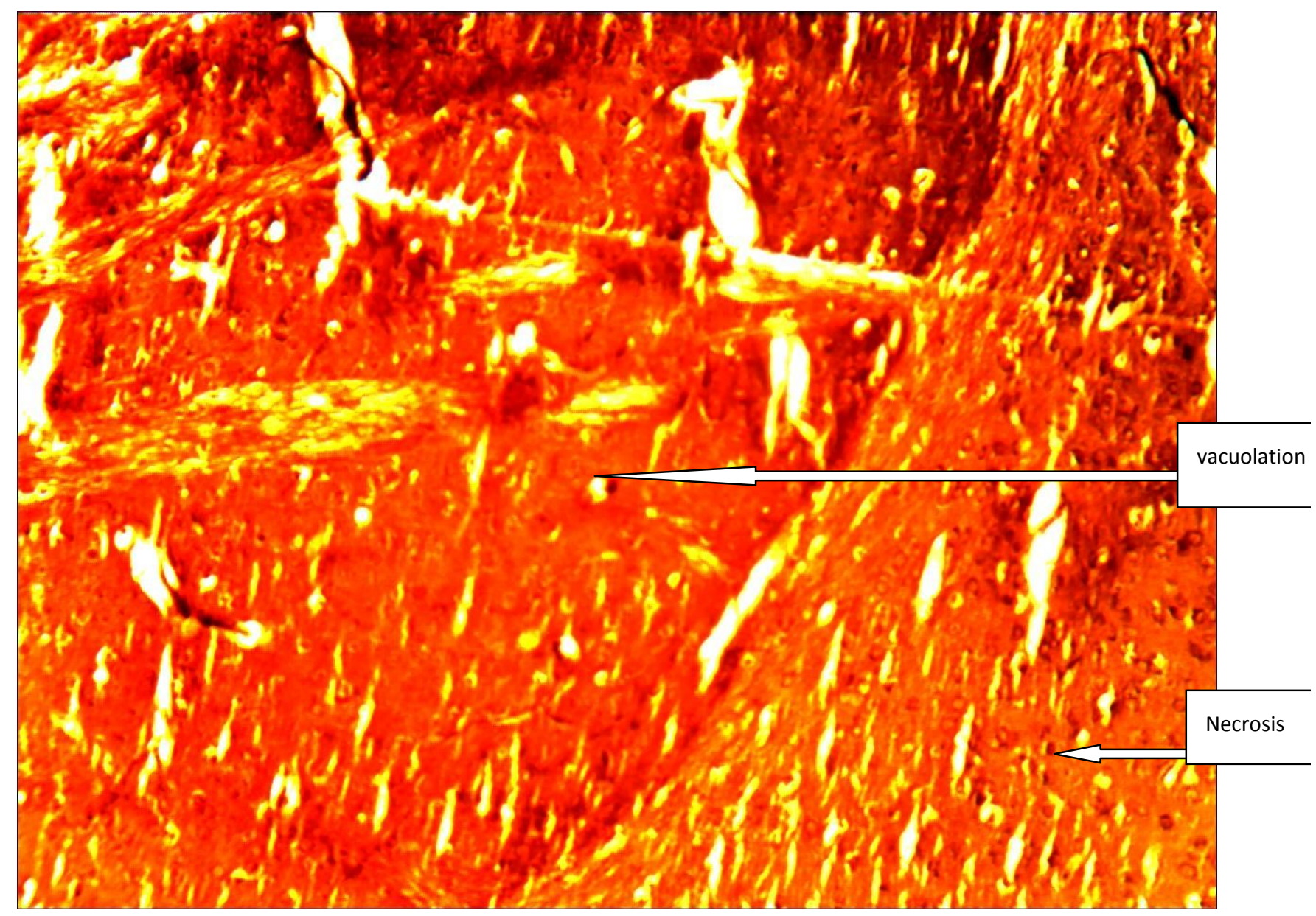

Plate 19. L.S. of extensive neuronal vacuolation and necrosis of the cerbral Cortex of wistar rats of group V .X100 


\section{MInstitute Macrink $_{\text {Insthe }}$}

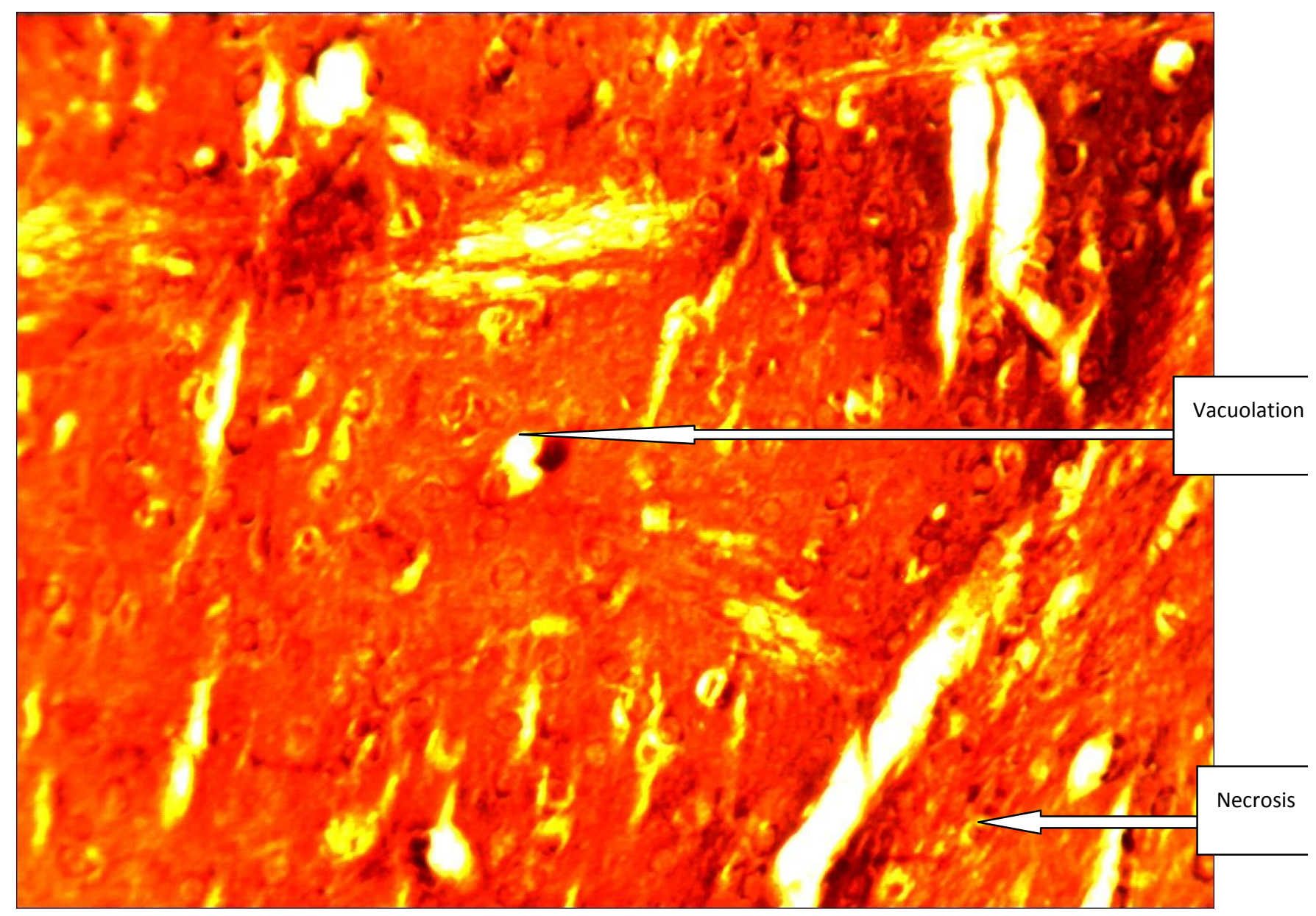

Plate 20.L.S. of extensive neuronal vacuolation and necrosis of the cerebral Cortex of wistar rats of group V.X250

\section{Discussion}

The cerebral cortex is the key structures of memory formation. It also integrates higher mental functions, general movement, visceral functions, and behavioral reactions. (Brodal, 1977; Cauller, 1995).

Aluminium was said to have contributed to a variety of cognitive impairments in mice, rabbits, and rat pups (Muller et al., 1990; Yokel, 1985, Bilkei-Gorzo, 1993; Mari, 2001). Behavioural impairment has also been reported in wistar rats exposed to soluble aluminium salts (chloride) in the drinking water (Buraimoh et al., 2011b).Both rats (Connor et al., 1988) and mice (Yen-Koo, 1992) have demonstrated such impairments at doses exceeding $200 \mathrm{mg}$ of aluminium per $\mathrm{kg}$ of body weight per day. Although significant alterations in acquisition and retention of learned behaviour were documented, the possible role of organ damage (kidney, liver, immunological) due to aluminium was incompletely evaluated in these studies (WHO, 1997).

Studies on workers exposed to Al dust in industrial environments demonstrate similar effects (Rifat, et al., 1990; Bast-pettersen, et al., 1994; White et al., 1992, Akila et al., 1999). Many researchers have found elevated $\mathrm{Al}$ levels to be associated with a decline in visual memory, 
attention, concentration, frontal lobe function and lower vocabulary scores in hemodialysis patients (Bolla et al., 1992). Aluminium chloride was said to have negative effects on anxiety-related behaviour of wistar rats as indicated by increased rate of anxiety in Aluminium treated rats (Buraimoh, et al., 2011c).Although, other reports on occupational Al exposure and neurological impairments demonstrate mixed findings (Sim et al., 1997). Despite strong experimental and clinical evidence for Al neurotoxicity, the mechanism of Al effects on the nervous system is still not completely clear.

In our present study, sections of the cerebral cortex were prepared from control and Al-exposed wistar rats and the effects of $\mathrm{Al}$ exposure on the cerebral cortex were histologically examined in order to describe any observed changes. A variety of histological changes were observed in the cerebral cortex of Aluminum exposed groups when compared with the control (Plates 1-20).

This research work has demonstrated that wistar rats exposure to aluminium chloride for a duration of eight weeks resulted into neuronal vacuolation and necrosis of the cerebral cortex which are form of neuro-degeneration (See Plates 3-10\&13-20). We also observed extensive neuronal vacuolation and necrosis in the highest dose Aluminium treated groups (plates 9-10\&plates 19-20). Since the Cerebral Cortex is said to play a key role in memory, attention, perceptual awareness, thought, language, and consciousness, then the neuro-degeneration (extensive vacuolation and necrosis) observed in the histology of the cerebral cortex of adult wistar rats could go a long way in affecting these functions(memory, attention, perceptual awareness, thought, language, consciousness, etc).

\section{Conclusion}

Our observations revealed that at higher dose exposure, extensive neuronal vacuolation and necrosis of cerebral cortex was evident, indicating loss of nissl substances. Mild vacuolar changes occur with empty spaces appear probably due to increased concentration of Aluminium toxicity. Based on our observation, we therefore conclude that Aluminium chloride exposure has neurodegenerative effects on the histology of cerebral cortex of adult wistar rats especially at higher dose. Therefore, caution should be taken in its usage.

\section{Acknowledgement}

The authors wish to acknowledge the Authority of Ahmadu Bello University, Zaria for providing an enabling environment for this research work.

\section{References}

Abbasali, K.M., Zhila, T., \& Farshad, N. (2005). Developmental Toxicity of aluminum from High Doses of $\mathrm{AlCl} 3$ in Mice. The Journal of Applied Research, 5: 575-579.

Akila, R., Stollery, B.T., \& Riihimaki V. (1999). Decrements in cognitive performance in metal inert gas welders exposed to aluminum. Occup Environ Med., 56:632-639. [PubMed].

Alfrey A.C. (1980). Aluminium metabolism in uremia. Neurotoxicology, 1:43-53. 
Alfrey, A.C., LeGendre, G.R., \& Kaehny, W.D. (1976). The dialysis encephalopathy syndrome. Possible aluminum intoxication. N. Engl. J. Med., 294: 184-188.

Bast-pettersen, R., Drablos, P.A., Goffeng, L.O., Thomassen, Y., \& Torres, C.G. (1994). Neuropsychological deficit among elderly workers in aluminum production. Am J Ind Med., 25:649-646. [PubMed]

Bilkei-Gorzo, A. (1993). Neurotoxic effect of enteral aluminum. Food Chem Toxicol., 31:357-361. [PubMed].

Bolla, K.I., Briefel, G., Spector, D., Schwartz, B.S., Wieler, L., Herron, J., \& Gimenez, L. (1992). Neurocognitive effects of aluminum. Arch Neurol., 49:1021-1026. [PubMed].

Bradbury, P. (1992).Histological Methods. In: Hewer's Textbook of Histology for Medical Students $9^{\text {th }}$ Ed. ELBS pp 431-450.

Brodal, S. (1977). The Central Nervous system: Structure and Function. Oxford University Press.

Buraimoh, A.A., Ojo, S.A., Hambolu, J.O., \& Adebisi, S.S. (2011a). Effects of Oral Administration of Aluminium Chloride on the Histology of the Hippocampus of Wistar Rats. Current Research Journal of Biological Sciences, 3(5): 509-515. ISSN: 2041-0778.

Buraimoh, A.A., Ojo, S.A., Hambolu, J.O., \& Adebisi, S.S. (2011b). Behavioural Enpoints of Adult Wistar Rats, Following Aluminium Chloride Exposure. British Journal of Pharmacology and Toxicology, 2(5): 273-276.ISSN: 2044-2467.

Buraimoh, A.A., Ojo, S.A., Hambolu, J.O., \& Adebisi, S.S. (2011c). Effects of Aluminium Chloride on Anxiety-Related Behaviour. American Journal of Neuroscience, 2(2): 65-69, 2011. http://dx.doi.org/10:3844/amjns.2011.

Campbell, A. (2002). The potential role of aluminium in Alzheimer's disease. Nephrol. Dial. Transplant., 17: 17-20.

Cauller, L. (1995). Layer I of primary sensory neocortex: where top-down converges upon bottom-up. Behav Brain Res., 71(1-2):163-70. PMID 874718.

Connor, D.J., Jope, R.S., \& Harrell, L.E. (1988). Chronic, oral aluminum administration to rats:Cognition and cholinergic parameters. Pharmacology, biochemistry, and behaviour, 31:467-474.

Culling, C. F. A. (1963). Handbook of Histopathological technique $2^{\text {nd }}$ Ed Butterworth's, London.

Exley, C.A. (2005). The aluminium-amyloid cascade 25. Brandeis, R., Y. Brandys and S. Yehuda, hypothesis and Alzheimer disease, Subcell. 1989. The use of the Morris water maze in the Biochem., 38: 225-234.

Flaten, T. (2001). Aluminium as a risk factor in Alzheimer's disease, with emphasis on drinking water. Brain Res. Bull., 55: 187-196. 
Gilbert, C.D. \& Sigman, M. (2007). Brain states: top-down influences in sensory processing. Neuron, 54(5):677-96. PMID 175534.

Gómez, M., Sánchez, D.J., Llobet, J.M., Corbella, J., \& Domingo, J.L. (1997). The effect of age on aluminium retention in rats. Toxicol., 116: 1-8.

Gupta, V.B., Anitha, G., Hegda, M.L., Zecca, L., Garruto, R.M., Ravid, R., Shankar, S.K., Stein, R., Hanmugavelu, P., \& Jagannatha Rao, K.S. (2005). Aluminium in Alzheimer's disease: are we still at a crossroad? Cell. Mol. Life Sc., 62: 143-158.

Gurr, E. (1962). Staining Animal Tissues, Practical and Theoretical Leoned Hill, London.

Hirano, A. \& Zimmerman, H.M. (1962). Arch. Neurol., 6:114-122.

Jones, E.G. (1998). Viewpoint: the core and matrix of thalamic organization. Neuroscience, 85(2):331-45. PMID 9622234

Klein, G.L. (1993). AluminIum and hepatobiliary complications of total parenteral nutrition. Gastroenterology, 10: 1583-1584.

Kloppel, H., Fliedner, A., \& Kordel, W. (1997). Behaviour and endotoxicology of aluminium in soil and water. Review of the scientific literature. Chemosphere., 35: 353-363.

Luna, L.G. (1968). Manual of Histologic Staining Methods of the AFIP 3rd Edition, McGraw-Hill, NY, c, p.195.

Mari, S., Golub, \& Stacey, L. (2001). Long-term consequences of developmental exposure to aluminum in a suboptimal diet for growth and behavior of Swiss Webster mice. Neurotoxicology and Teratology., 23:365-372. [PubMed].

Muller, G., Bernuzzi, V., Desor, D., Hutin, M.F., Burnel, D., \& Lher, P.R. (1990). Developmental alteration in offspring of female rats orally intoxicated by aluminum lactate at different gestation periods. Teratology, 42:253-261. [PubMed].

Newairy, A.S., Salama, A.F., Hussien, H.M., \& Yousef, M.I. (2009). Propolis alleviates aluminium-induced lipid peroxidaion and biochemical parameters in male rats. Food Chem Toxicol, 47(6):1093-8.

Niu, Q., Yang, Y., Zhang, Q., Niu, P., HE, S., Di Gioacchino, M., \& Boscolo, P. (2007). "The relationship between Bcl-2 gene expression and learning \& memory impairment in chronic aluminum-exposed rats. Volume 12, Number 3, 163-169, http://dx.doi.org/10.1007/BF03033913.

Rifat, S.L., Eastwood, M.R., McLachlan, D.R.C., \& Corey, P.N. (1990).Effect of exposure of miners to aluminum powder. Lancet., 336:1162-1165. [PubMed].

Sahin, G., Varol, I., \& Temizer, A. (1994). Determination of aluminium levels in the kidney, liver, and brain of mice treated with aluminium hydroxide. Biol. Trace. Element Res., 41: 129-135. 


\section{Macrothink}

Shehla, K.F., Prabhavathi, P.A., Padmavathi, P., \& Reddy, P.P. (2001). Analysis of chromosomal aberrations in men occupationally exposed to cement dust.". Mutat Res., 490: 179-186.

Shipp, \& Stewart, (2007). Structure and functions of the cerebral cortex Current Biology, 17 (12): $\quad$ R443-9. $\quad$ http://dx.doi.org/10.1016/j.cub.2007.03.044. $\quad$ PMID 17580069 http://www.cellcom/current-biology/retrieve/pii/S0960982207011487.

Sim, M., Dick, R., Russo, J., Bernard, B., Mueller, C., \& McCammon, C. (1997). Are aluminum potroom workers at increased risk of neurological disorders? Occup Environ Med., 54:229-235. [PubMed].

White, D.M., Longstreth, W.T., Rosentock, L., Keith, H.J., Clay-poole, H.J., Brodkin, C.A.,\& Townes, B.D. (1992).Neurological syndrome in 25 workers from an aluminum smelting plant. Arch Intern Med., 152:1443-1448. [PubMed]

WHO, (1997) Aluminium. Geneva, World Health Organization, International Programme onChemical Safety (Environmental Health Criteria 194.

Wills, M.R., Hewitt, C.D., Sturgill, B.C., Savory, J., \& Herman, M.M. (1993). Long-term oral or intravenous aluminium administration in rabbits.I. Renal and hepatic changes. Ann. Clin. Lab Sci., 23: 1-16.

Yen-Koo, H.C. (1992). The effect of aluminum on conditioned avoidance response (CAR) inmice. Toxicology and industrial health, 8:1-7.

Yokel, R.A. (1985). Toxicity of gestational aluminum exposure to the maternal rabbit and offspring. Toxicol Appl Pharmacol., 79:121-133. [PubMed] .

Yokel, R.A. (2000). The toxicology of Aluminium in brain: review, Neurotoxicology, 21(5):813-828.

Yokel, R.A., \& McNamara, P.J. (2001). Aluminum toxico kinetics: an updated mini review. Pharmacol. Toxicol., 88: 159-167.

\section{Copyright Disclaimer}

Copyright reserved by the author(s).

This article is an open-access article distributed under the terms and conditions of the Creative Commons Attribution license (http://creativecommons.org/licenses/by/3.0/). 